\title{
Peran Lembaga Muhammadiyah dalam Mitigasi Bencana di Kabupaten Sinjai
}

\author{
Kiki Rasmala Sani ${ }^{1}$, Syamsuddin ${ }^{2}$ \\ 1,2Program Studi Ilmu Administrasi Publik, STISIP Muhammadiyah Sinjai, Kabupaten Sinjai, 92612, \\ kikirasmalasani313@gmail.com¹, syam.sinjaiku@gmail.com²
}

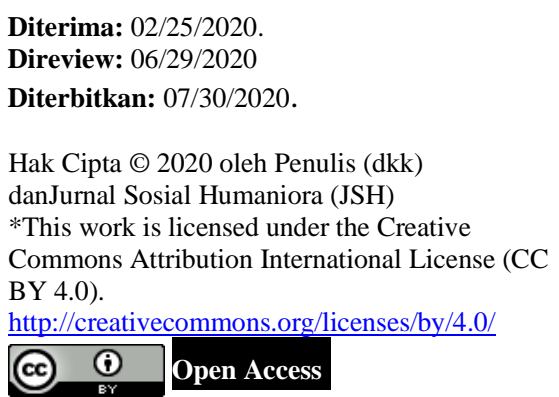

Diterima: $02 / 25 / 2020$

Direview: 06/29/2020

Diterbitkan: 07/30/2020.

(J)

danJurnal Sosial Humaniora (JSH)

Commons Attribution International License (CC

BY 4.0)

(c) (1) Open Access

\begin{abstract}
Subject Area: Social and Politics (Sosial dan Politik)
Abstract

This study aims to analyze the role of the Muhammadiyah Institute in disaster mitigation in Sinjai region. As a large organization in Sinjai, Muhammadiyah serves as the government's partner in promoting disaster preparedness to the public via institutions that were founded on the level of Regional Leadership and the level of business charity. This research uses descriptive analysis with qualitative methods. The respondents were Muhammadiyah Regional Leaders, Muhammadiyah Disaster Management Institutions, and Muhammadiyah cadres in the Sinjai region. The results of this study indicated that the institution, since the Regional Leadership of Muhammadiyah Sinjai founded it, had not had a work program. Thus, the agency has not yet significantly contributed to disaster mitigation. All cadres who exist in the structure of the institution are cadres in various other organizations that can be resources in achieving organizational goals
\end{abstract}

Keywords: disaster mitigation; institution; Muhammadiyah.

\section{Latar Belakang}

Bencana alam yang terjadi merupakan sebuah ancaman bagi masyarakat dan mengganggu kehidupan dimana bencana tersebut berdampak terhadap timbulnya korban jiwa manusia, kerusakan lingkungan, kerugian harta benda, dan dampak psikologis yang berkepanjangan. Asian Disaster Reduction Centerand the United Nations mendeskripsikan bencana sebagai suatu gangguan serius terhadap fungsi masyarakat yang mengakibatkan kerugian manusia, material, atau lingkungan yang luas melebihi kemampuan masyarakat yang terkena dampak dan harus mereka hadapi menggunakan sumber daya yang dimiliki (Kusumasari, 2014)

Bencana dalam konteks Muhammadiyah di definisikan sebagai "gangguan serius yang disebabkan baik oleh factor alam maupun faktor manusia, yang bisa melumpuhkan fungsifungsii masyarakat yang dibangun untuk menopang keberlangsungan hidup, melindungi asset-aset, kelestrian lingkungan dan menjamin martabatnya sebagai manusia, sebagai bagian dari perintah agama". Lumpuhnya fungsi tersebut karena terjadinya kerugian dari sisi manusia, materi, ekonomi, atau lingkungan yang meluas melampaui kemampuan komunitas atau masyarakat yang terkena dampak untuk mengatasi dengan menggunakan sumberdaya mereka sendiri (Berita Resmi PP Muhammadiyah, 2019).

Kabupaten Sinjai terletak di Provinsi Sulawesi Selatan dan terdiri dari daerah pegunungan dan laut yang memilki resiko bencana atau rawan bencana. Sejarah bencana yang terjadi di Kabupaten Sinjai salah satunya bencana banjir bandang yang terjadi di tahun 2006. Bencana banjir bandang dan tanah longsor banyak 
memakan korban dan mengakibatkan kerusakan-kerusakan baik infrasturktur daerah, rumah masyarakat maupun kerusakan lingkungan. Potensi bencana di Kabupaten Sinjai juga terdapat potensi angin kencang atau puting beliung yang terdapat di daerah pegunungan serta kerawanan bencana gempa bumi wilayah pesisir dan lautnya. Berdasarkan hasil kajian Badan Penelitian dan Pengembangan Daerah Kabupaten Sinjai telah melakukan pengkajian dan pemetaan wilayah bencana di Kabupaten Sinjai diantaranya potensi bencana banjir, angin kencang, banjir, tanah longsor dan kerawanan tektonik (gempa bumi dan tsunami).

Dengan keadaan yang sangat rawan bencana, seyogyanya masyarakat perlu paham terkait apa yang harus dipersiapkan. Dengan memahami dan menyadari kemungkinan bencana yang mungkin menghampiri, masyarakat sudah punya persiapan. Tidak hanya tentang bagaimana menyelamatkan diri tetapi juga agar potensi kerugian akibat bencana bisa di minimalisir. Penelitian yang dilakukan oleh (Rahman, 2015) terkait mitigasi bencana tanah longsor di Kabupaten Banjarnegara menunjukan bahwa upaya mitigasi bencana tanah longsor yang dilaksanakan melalui mitigasi structural dilakukan dengan penyusunan data base daerah potensi bahaya dan pemasangan Early Warning System (EWS). Mitigasi non-struktural dilakukan dengan pemberian informasi, sosialisasi serta pelatihan dan simulasi bencana. Upaya tersebut dilaksanakan dengan tujuan meningkatkan efektifitas mitigasi bencana dengan pembentukan masyarakat tangguh serta desa tangguh bencana.

\section{Tinjauan Pustaka}

Menurut (Dewi, Istiadi, \& Istiadi, 2016) bahwa berbagai potensi bencana alam terkait perubahan iklim dapat menimbulkan kerugian dalam bentuk kehilangan harta benda dan korban jiwa. Potensi kerugian yang ditimbulkan oleh bencana tersebut, dapat dikurangi melalui mitigasi. Mitigasi diartikan sebagai upaya mengurangi dan mencegah risiko kehilangan jiwa dan harta benda baik melalui pendekatan struktural maupun non-struktural. Lebih lanjut, menurut (Sugiharyanto et. al., 2014), mitigasi struktural merupakan upaya pengurangan risiko bencana melalui pembangunan fisik serta rekayasa teknis bangunan tahan bencana, sedangkan mitigasi nonstruktural adalah upaya pengurangan risiko bencana yang bersifat non fisik seperti kebijakan, pemberdayaan masyarakat, penguatan institusi, kepedulian.

Lebih lanjut, (Dewi et al., 2016) yang meneliti tentang mitigasi bencana pada masyarakat tradisional dalam menghadapi perubahan iklim di Kampung Naga menyatakan bahwa kemampuan mitigasi bencana masyarakat dipengaruhi kearifan tradisional yang tercermin dari konservasi hutan, bangunan, infrastruktur dan pola ruang kampong yang dapat mengurangi ancaman bencana tanah longsor dan banjir. Proses penyadaran dan pemberian pemahaman sadar bencana tidak hanya menjadi tugas pemerintah, tetapi seluruh elemen masyarakat yang memang punya basic kegiatan ditengah masyarakat. Pada posisi inilah, Persyarikatan Muhammadiyah sebagai salah satu organisasi yang besar memiliki kemampuan dalam kegiatan-kegiatan terkait kebencanaan tersebut.

Penanggulangan bencana adalah bagian dari nafas pergerakan Muhammadiyah sejak pendiriannya di tahun 1912. Salah satu bentuk amal nyata dalam bidang penanggulangan bencana berdirinya Lembaga Penanggulangan Bencana Muhammadiyah atau disebut juga Muhammadiyah Disaster Management Center dengan singkatan MDMC. Berdasarkan SKPP Muhammadiyah No. 58/KEP/I.0/2007 tentang penetapan Pengurus Pusat Pengulangan Bencana PP Muhammadiyah yang kemudian dikenal dengan MDMC dengan 
ketuanya Dr. H. M. Natsir Nugroho, Sp.Og., M. Kes. (Slamet et al., 2018), MDMC bergerak dalam kegiatan kebencanaan di seluruh wilayah Negara Republik Indonesia, sesuai wilayah badan hukum Persyarikatan Muhammadiyah yang dalam operasionalnya mengembangkan MDMC di tingkat Pimpinan Wilayah Muhammadiyah (Propinsi) dan MDMC di tingkat Pimpinan Daerah Muhammadiyah (Kabupaten).

Peran MDMC dalam bencana di Indonesia sebagaimana penelitian yang dilaksanakan oleh (Akbar, 2012) terkait recovery bencana merapi yang dilakukan Muhammadiyah menunjukkan bahwa jejaring yang dimiliki Muhammadiyah sangat erat. Hal ini ditunjukkan dengan hubungan antar lembaga/majelis yang bernaung dibawah muhammadiyah mampu bersatu dalam menyukseskan upaya recovery korban bencana merapi. Dan koneksi tersebut dikoordinasi melalui MDMC yang secara terstruktur dan rapi menyusun berbagi program dan kegiatan dalam proses recovery tersebut.

Selain itu, (Putra, 2018) meneliti tentang kesiapsiagaan Tim Komite Bencana Rumah Sakit PKU Muhammadiyah Bantul dalam menghadapi bencana. Hasil penelitian menunjukkan bahwa Tim komite penanggulangan bencana rumah sakit secara resmi telah dibentuk oleh Rumah Sakit PKU Muhammadiyah Bantul untuk menanggapi keadaan bencana dan memiliki kesigapan dalam mempersiapkan berbagai kemungkinan bencana yang memang rawan terjadi di Kabupaten Bantul.

Kelembagaan mitigasi memiliki tujuan untuk mengurangi dampak resiko, suatu kegiatan kelembagaan dapat disebut efektif ketika tujuannya tercapai. Strategi penanggulangan bencana memiliki sasaran terbentuknya kelembagaan penyelengaraan penanggulangan bencana dengan kapasitas yang memadai pada sistem, desentraliasi kewenangan dan kemitraan yang ditunjang dengan dasar hukum yang kuat dalam pelaksanaanya. (Baidhawy, 2015; Larasati, 2016) menyebutkan bahwa, pencapaian terbentuknya kelembagaan dalam penanggulangan bencana (manajemen bencana), difokuskan pada penguatan dasar hukum untuk penanggulangan bencana yang terkoordinasi dan Penguatan kapasitas kelembagaan dalam penaggulangan bencana dan sistem pendukungnya. Menurut (Kusumasari, 2014 \& Nugroho, Mustam, \& Lituhayu, 2015) menjelaskan bahwa respon/daya tanggap mempunyai tujuan untuk koordinasi penilaian kebutuhan di lokasi terjadi bencana agar pihak yang dikoordinasikan dapat datang dilokasi kejadian sehingga penilaian kebutuhan dapat dicapai.

Kelembagaan menurut (Wulandari, Budiono, \& Nurrochmat, 2016) merupakan suatu tatanan atau pola hubungan antara anggota masayarakat atau organisasi yang saling mengikat yang dapat menentukan bentuk hubungan antara masyarakat atau antar organisasi, yang diwadahi dalam suatu organisasi atau jaringan dan ditentukan oleh faktor- faktor pembatas dan pengitkat berupa norma, kode etik aturan formal atau informal untuk pengendalian perilaku sosial serta intesif untuk bekerjasama dan mencapai tujuan bersama. Ada beberapa elemen kelembagaan yang diperlukan seperti infrastruktur kelembagaan, penataan kelembagaan, mekanisme kelambagaan. Hal tersebut diatas telah menjelaskan bahwa, kelembagaan dalam hal ini perlu adanya kelengkapan sarana dan prasarana atau infrastuktur sebagai wadah dalam menyusun strategi penanggulangan bencana atau manajemen bencana. Selain itu, penataan kelembagaan diperlukan guna mengefektifkan koordinasi dalam pelaksanaan strategi manajemen bencana sehingga tujuan lembaga dapat tercapai. Mekanisme kelembagaan yang disusun untuk kesiapan atau kesiapsiagaan dalam menghadapi kemungkinan terjadinya bencana, sehingga dapat memaksimalkan penangan atau tanggap darurat suatu bencana alam ketika terjadi. 
Mitigasi bencana merupakan bagian dari pra-bencana yang meliputi serangkaian upaya dilakukan untuk mengurangi resiko bencana. Dalam PP No. 21 Tahun 2008 disebutkan bahwa mitigasi merupakan serangkaian upaya untuk mengurangi resiko bencana, baik melalui pembangunan fisik maupun penyadaran dan peningkatan kemampuan menghadapi ancaman bencana, yang dilakukan melalui :

a. Perencanaan dan pelaksanaan penataan ruang yang berdasarkan pada analisis resiko bencana;

b. Pengaturan pembangunan, pembangunan infrastruktur dan tata bagungunan;

c. Penyelenggraaan pendidikan pelatihan, dan penyuluhan baik secara konvensional maupun modern. Menurut (Kusumasari, 2014), ada dua jenis mitigasi yaitu :

a. Mitigasi struktural merupakan pembangunan atau perubahan lingkungan yang dilakukan untuk mengurangi resiko melalui penerapan solusi yang dirancang. Upaya ini dilakukan mencakup ketahanan konstruksi, langkah- langkah pengaturan, kode bangunan, relokasi, modifikasi struktur, konstruksi tempat tinggal masyarakat, konstruksi batas wilayah atau sistem pendeteksi, modifikasi fisik, sistem pemulihan, dan penanggulangan infrastruktur untuk keselamatan hidup.

b. Mitigasi non-struktural, terdiri dari modifikasi proses-proses perilaku manusai atau alam, tanpa membutuhkan penggunaan struktur yang dirancang sebagai bentuk pengurangan kemungkinan atau konsekuensi resiko. Didalam teknik ini terdapat langkah- langkah regulasi, program pendidikan, dan keadaran masyarakat, modifikasi non struktural, modifikasi perilaku serta pengendalian lingkungan.

Muhammadiyah menitikberatkan pada jenis mitigasi non-struktural yaitu pendekatan yang bukan fisik dan teknis seperti legislasi, regulasi soal tata ruang dan lahan, pendidikan dan penguatan kapasitas masyarakat. Posisi Muhammadiyah kemudian adalah menumbuhkan gerakan membumikan sadar bencana sebagai salah satu ikhtiar mitigasi bencana. Dengan demikian, masyarakat dapat menyusun rencana-rencana kesiapsiagaan bencana sehingga dapat mengurangi resiko bencana yang kemudian akan dihadapi.

Dengan berbagai potensi bencana yang juga rentan di Kabupaten Sinjai dan untuk membantu kelancaran kinerja organisasi di Kabupaten Sinjai, Pimpinan Daerah Muhammadiyah membentuk Lembaga Penanggulangan Bencana (LPB). Dengan adanya lembaga tersebut, seyogyanya, Muhammadiyah hadir dalam berbagai kegiatan yang berkenaan dengan kebencanaan baik dalam pencegahan maupun trauma healing sehingga lembaga yang dibentuk tidak hanya menjadi kelengkapan struktural pimpinan daerah Muhammadiyah namun juga memiliki kontribusi sebagaimana tujuan MDMC didirikan.

Penelitian ini akan membahas tentang peran Lembaga Penanggulangan Bencana Muhammadiyah dalam melakukan penanganan bencana dan mitigasi bencana di Kabupaten Sinjai Penelitian ini mennitikberatkan pada pelaksanaan program terkait mitigasi yang telah dan akan dilaksanakan oleh Lembaga Penanggulangan Bencana Muhammadiyah Pimpinan Daerah Muhammadiyah Sinjai

\section{Metode Penelitian}

Penelitian ini menggunakan metode deskriptif dengan pendekatan kualitatif. Adapun informan dalam penelitian ini adalah Pimpinan Daerah Muhammadiyah, pengurus Lembaga Penanggulangan Bencana dan kader Muhammadiyah Kabupaten Sinjai.

Untuk mengumpulkan data dalam penelitian ini, tekhnik yang digunakan adalah wawancara mendalam 
(in-depth interview) untuk mencapai informasi yang spesifik dan mendalam serta sebagai bentuk konfirmasi atas dokumen-dokumen yang dikumpulkan. Pemilihan informan kunci didasarkan pada struktur organisasi Pimpinana Daerah Muhammadiyah (PDM) dan pengurus Lembaga Penanggulangan Bencana, antara lain Ketua PDM Kabupaten Sinjai; Sekretaris PDM, Ketua Majelis PDM, Ketua Lembaga Penanggulangan Bencana PDM; Anggota Lembaga Penanggulangan Bencana; dan kader Muhammadiyah Kabupaten Sinjai..

Untuk menganalisis data yang telah diperoleh, dilakukan dengan mendasarkan kepada asumsi jawaban dari pertanyaan penelitian yang telah dibuat, dengan melalui tahapan dalam bentuk tujuan penelitian yang ingin dicapai. Dalam hal ini proses kegiatan analisis data meliputi a) tahap pengumpulan data, b) mereduksi data untuk mendapatkan pokok-pokok tema yang dianggap memiliki relevansi dengan masalah penelitian, c) penilaian data, yang dilakukan dengan cara mengkategorikan data primer dan data sekunder dengan sistem pencatatan yang relevan, d) menginterpretasikan data, yang dilakukan dengan cara menganalisis secara kritis data yang terkumpul dan pada akhirnya sampai kepada suatu kesimpulan.

\section{Hasil Penelitian dan Pembahasan}

Lembaga Penanggulangan Bencana Pimpinan Daerah Muhammadiyah (LPB PDM) Sinjai di bentuk pada pada tanggal 17 Agustus 2016 atau bertepatan dengan 14 Dzulqa'dah 1437 H, yang bertugas periode 2016-2020. Ketua PDM Sinjai mengatakan bahwa

\footnotetext{
"Pembentukan Lembaga ini dari awal sebagai bagian dari usaha Pimpinan Daerah dalam rangka membanun kesadaran bencana paling tidak dikalangan kader Muhammadiyah Sinjai. karena Sinjai sangat besar potensi bencananya. Dan PDM memilih orang-orang ini karena tahu latar belakangnya cakap terkait kebencanaan".
}

LPB PDM Sinjai ini memiliki modal untuk mengembangkan lembaga. Mereka yang tergabung dalam struktur kepengurusannya adalah bagian dari Palang Merah Sinjai dan Tim Reaksi Cepat (TRC) serta Search and Rescue (SAR) Badan Penanggulangan Bencana Daerah Kabupaten Sinjai sehingga secara kesiapan, sesuangguhnya mereka memiliki modal besar dan kecakapan dalam penanggulangan bencana. Dalam rangka sosialisasi dan peningkatan SDM, maka berdasarkan Surat dari Pimpinan Wilayah Muhammadiyah Sulawesi Selatan No: 004/II.8/B/2017 terkait Pelatihan SAR, PDM Sinjai kemudian memandatir 8 orang terdiri dari pejabat LPB PDM dan perwakilan dari HW dan IMM untuk mengikuti kegiatan tersebut. Kegiatan tersebut dilaksanakan pada Juli 2017 di Kabupaten Bantaeng, Sulawesi Selatan. Berdasarkan data dokumentasi, hanya kegiatan inilah yang diikuti oleh LPB PDM Sinjai. Bahkan tidak ada tindak lanjut dari pertemuan tersebut.

Peran Lembaga dalam mitigasi bencana sejak dibentuknya hingga saat ini bisa dikatakan masih belum jelas. Program kerja belum ada yang tersusun dan terlaksana. Ketua Lembaga Penanggulangan Bencana, A. Arifuddin mengatakan "Sering membicarakan program. Namun tidak ada rencana yang disusun". Lebih lanjut, Sekretaris LPB mengatakan

\footnotetext{
"Sebenarnya ingin menyusun program. Namun sulit mempertemukan seluruh anggota karena kesibukan masing-masing. Selain itu, juga karena belum jelas terkait sumber pendanaan. Kader yang masuk struktur ini rata-rata sibuk. Ada yang mengajar, ada yang kuliah, ada yang sibuk di kantor tempat bertugas, Jadi, susah ketemu. Akhirnya sampai sekarang, jangankan program. Rencana saja belum ada yang jadi”.
}

Berdasarkan wawancara dan observasi, beberapa hal yang menyebabkan nihilnya program kerja LPB PDM Sinjai disebabkan oleh beberapa hal. Pertama pembentukan majelis dan lembaga di tubuh PDM Sinjai seringkali dilaksanakan dengan tidak dihadiri oleh seluruh tokoh, kader dan simpatisan Muhammadiyah. Oleh 
karenanya, untuk penyusunan personalia hanya ditetapkan berdasarkan masukan-masukan dari kader yang hadir tanpa dilakukan konfirmasi kesediaan terlebih dahulu. Akibatnya adalah, kemungkinan masih ada anggota majelis dan lembaga yang tidak tahu akan posisinya dalam struktur majelis dan lembaga. Salah satu kader menyatakan

"sulit sebenarnya membuat program karena kadang rapat pembentukan struktur tidak dihari seluruh kader. Nah, kalau mau membentuk lembaga, tentu saja jika hanya mengandalkan kader hadir rapat, maka strukturnya tidak akan lengkap. Sehingga kadang ditunjuk saja siapa yang dianggap sesuai di posisi itu, itulah yang dipilih dalam struktur lembaga meski yang bersangkutan belum dikonfir mau tidaknya".

Akibatnya adalah, kemungkinan masih ada anggota majelis dan lembaga yang tidak tahu akan posisinya dalam struktur majelis dan lembaga. Selain itu, setelah pembentukan dilaksanakan, raker yang seharusnya dilaksanakan atau musyawarah yang melibatkan seluruh majelis dan lembaga tidak dihadiri oleh seluruh personalia yang sudah di SK-kan sehingga sulitnya mengatur jadwal pertemuan dalam rangka menyatukan persepsi terkait program yang akan dilaksanakan kemudian. Hal terebut memberikan kesan bahwa lembaga atau majelis yang dibentuk memang ada namun, untuk kegiatan tertentu yang melibatkan mereka hanya diikuti dan dilaksanakan oleh beberapa orang saja.

Kedua, Faktor kesibukan masing-masing pribadi di luar Muhammadiyah juga mengakibatkan tidak adanya program yang diinisiasi sebab personalia LPB Muhammadiyah ada yang berprofesi sebagai guru, mahasiswa dan pegawai instansi di Kabupaten Sinjai. Sehingga walaupun organisasi eksternal ini menjadi modal namun juga menjadi permasalahan sebab kesibukan menyebabkan sulitnya membagi waktu untuk mengembangkan persyarikatan.

"ada yang guru di lokasi terpencil dan waktunya terbatas di Sinjai. sehingga kalau ada rapat, jarang hadir. Yang kerja di instansi juga sibuk di kantor. Yang kuliah kebanyakan di Makassar jadi sibuk semua. Susah mengadakan rapat"

Ketiga, selain permasalahan diatas, salah satu hal yang menjadi permasalahan juga adalah terkait pendanaan kegiatan. Meskipun menjelang akhir tahun 2019 pengurus LPB Muhammadiyah berkeinginan untuk melaksanakan pendidikan dasar dan perekrutan anggota, namun karena terkendala biaya, akhirnya program yang direncanakan tidak terlaksana hingga memasuki tahun 2020. Menurut salah satu informan "Kalau ada kegiatan sulit pendanaan karena harus mengurus proposal dana ke PDM, ke Cabang dan amal usaha. Itupun juga dana yang tersedia minim".

Keempat, Kegiatan yang selama ini dilaksanakan terkait bencana hanya dalam tahap recovery bencana meliputi pemberian bantuan bagi masyarakat yang terkena bencana maupun terjun langsung dalam upaya evakuasi pada berbagai bencana di Kabupaten Sinjai dan di daerah lain seperti Palu Sulawesi Tengah, pasca bencana Tsunami dan likuifaksi beberapa waktu lalu.

"Untuk aspek koordinasi, sebenarnya cukup bagus. Jadi kalaupun misalnya LPB tidak aktif, tetap ada koordinasi dengan PDM kalau ada bencana. Jadi, PDM tetap mendukung jika ada kader yang akan akan membawa bantuan ke lokasi bencana atau ada kader yan mau jadi relawan. Jadi kader tetap ambil bagian dalam bencana meskipun memang dalam hal pencegahan atau mitigasi belum ada"

Hal ini diperkuat dengan pernyataan salah satu kader Muhammadiyah

"Secara individual, kader cukup aktif untuk bantuan kebencanaan. Selain itu, PDM juga tetap mengapresiasi amal usaha yang kemudian menbentuk lembaga penanggulangan bencana tingkat perguruan tinggi sehingga sebenarnya tinggal membangun koordinasi saja agar bias bersinergi".

Kelima, belum memaksimalkan komunikasi organisasi, misalnya menggunakan media social atau 
aplikasi lainnya untuk menunjang tugas dan tanggung jawab organisasi. Sehingga kesulitan terkait menghadiri pertemuan atau rapat dapat dilaksanakan dengan mudah.

Berbagai permasalahan diatas dapat diatasi dengan menata kembali aspek kepemimpinan dan sinergitas organisasi. Baik di Pimpinan Daerah Muhammadiyah maupun dalam struktur LPB Muhammadiyah itu sendiri. Pemimpin yang efektif adalah pemimpin yang berhasil mengarahkan dan menggerakkan seseorang dan kelompok untuk melaksanakan seluruh kegiatan yang telah direncanakan dalam usaha untuk mencapai tujuan yang telah ditetapkan (Rahman, 2015). Aspek kepempinan ini dibutuhkan agar, semua majelis dan lembaga dibawah naungan PDM Sinjai dapat menyatukan gerak dalam rangka mengemban tugas dan tupoksinya. Sehingga, semua bidang dapat menyusun program dan melaksanakan program masing-masing namun tetap tidak dapat mengesampingkan kerjasama atau "kolektif kolegial" yang dipegang teguh oleh warga Muhammadiyah.

Aspek sinergitas juga penting dalam organisasi. Komunikasi dan koordinasi adalah dua hal yang tidak bias dipisahkan dalam rangka mencapai tujuan. Saluran komunikasi dalam organisasi merupakan proses penyampaian pesan antar anggota-anggota organisasi yang terjadi untuk kepentingan organisasi, seperti halnya komunikasi antara atasan dan bawahan maupun antara sesama bawahan (Rahman, 2015). Aspek komunikasi berperan dalam menyatukan persepsi dan membangun kerjasama. Yang terakhir adalah aspek koordinasi. Tujuan yang ingin dicapai tersebut biasanya tidak dapat, atau kurang efisien, bila dikerjakan secara individu (Juliawati, 2013). Dengan koordinasi yang dibangun baik secara horizontal maupun vertikal, maka sinergitas PDM dan LPB Muhammadiyah serta seluruh kader Muhammadiyah dapat terlaksana. Aspek-aspek sinergitas inilah yang memiliki andil dalam persyarikatan dan perlu dibangun sehingga peran Muhammadiyah menujuislam yang berkemajuan dapat dimanifestasikan dengan memberi manfaat yang maksimal bagi masyarakat umum.

Komunikasi dan koordinasi adalah dua hal yang tidak bias dipisahkan dalam rangka mencapai tujuan sehingga mereka mampu memaksimalkan potensi yang dimiliki seperti:

1. Muhammadiyah merupakan organisasi yang besar di Kabupaten Sinjai; Sebagai organisasi yang besar dan berkembang di Kabupaten Sinjai, maka dalam berbagai kegiatan seharusnya sudah dapat berjalan dengan maksimal. Apalagi program kerja di tingkat majelis dan lembaga. Dengan perkembangan Muhammadiyah di Sinjai, maka komunikasi dan kerjasama dapat dijalin dengan berbagai pihak yang diinisiasi oleh kader. Sehingga dengan demikian hal ini dapat menjadi modal yang cukup besar didalam menyukseskan berbagai program yang disusun di tingkat pimpinan daerah maupun amal usaha

2. Personalia aktif di organisasi Palang Merah Indonesia dan Badan Penanggulangan Bencana Daerah Kabupaten Sinjai; Badan Penanggulangan Bencana Daerah, Palang Merah Indonesia, Dinas Lingkungan Hidup dan lain-lain menjadi institusi yang juga banyak dijabat oleh kader Muhammadiyah. Dengan demikian, hal tersebut dapat memudahkan Lembaga Penanggulangan Bencana dalam menyusun dan melaksanakan program kerja serta bekerja sama dengan instansi di luar PDM. Kesibukan dalam mengerjakan tugas utama menjadi tantangan dalam persyarikatan meskipun jika dikelola dengan baik, aspek ini dapat bermanfaat didalm membangun kerjasama dengan pihak luar sehingga mendukung program dan kegiatan Muhammadiyah. 
3. Amal Usaha Muhammadiyah (AUM) di bidang pendidikan; Amal Usaha Muhammadiyah di Kabupaten Sinjai adalah pendidikan. Hal tersebut dapat menjadi media dalam melaksanakan mitigasi non-struktural yakni pendidikan, pelatihan dan penyebarluasan informasi. Dengan memberikan pendidikan sadar bencana dan juga dapat menyebarluaskan informasi kepada masyarakat dalam berbagai kegiatan. Baik yang dilaksanakan guru/dosen maupun yang dilaksanakan oleh siswa dan mahasiswa. Untuk ditingkat perguruan tinggi juga sudah dibentuk Lembaga Penanggulangan Bencana dan Search and Rescue (LPB \& SAR) dan LazizMu yang berfungsi untuk melaksanakan kegiatan penanggulangan bencana dan pemberian bantuan pada korban bencana, tidak hanya di Kampus tetapi juga di luar kampus. Kedua lembaga inilah yang lebih banyak berkontribusi dalam berbagai kegiatan penanggulangan bencana di Kabupaten Sinjai dan juga di daerah-daerah lain. Meskipun mereka merupakan bentukan dari perguruan tinggi, tetapi juga tetap menjalin koordinasi dengan PDM dalam hal ini sebagai bagian dari amal usaha.

4. Telah ada Nota Kesepahaman antara Badan Penanggulangan Bencana Nasional dengan Pimpinan Pusat Muhammadiyah tentang: a) Penanggulangan Bencana dengan tujuan untuk saling mendukung dan menguatkan dalam penangulangan bencana. Peningkatan kapasitas sumber daya dalam penyelenggaraan penanggulangan bencana meliputi pendidikan, pelatihan, motivasi, dan pengembangan teknologi; b) Penyelenggaraan penanggulangan bencana dengan melibatkan berbagai pihak pada masa prabencana, saat bencana dan pasca bencana c) Penyelenggaraan pelayanan untuk masyarakat dalam pemenuhan kebutuhan berbasis hak kepada masyarakat pada fase pra bencana, tanggap bencana dan pascabencana di dalam negeri maupun di tingkat internasional d) Penyelenggaraan forum bersama, konsultasi nasional, seminar-seminar, pameran, workshop, ataupun riset di bidang penanggulangan bencana. Dengan adnya nota kesepahaman ini, maka di tingkat propinsi dan daerah sebaiknya telah mengadakan inisiasi untuk membuat MoA pula dengan BPB Provinsi maupun BPBD Kabupaten Sinjai sehingga kemudian dapat menjalin kerjasama dalam rangka penanggulangan bencana provinsi dan daerah. Namun, hingga saat ini hal tersebut juga belum terlaksana.

\section{Kesimpulan}

LPB PDM Sinjai yang terbentuk belum melaksanakan program kerja mitigasi bencana dengan berbagai kendala. Meskipun demikian, untuk kegiatan recovery, kader-kader Muhammadiyah di Kabupaten Sinjai cukup aktif baik secara pribadi maupun melalui Lazis Muhammadiyah dalam memberikan bantuan bagi korban bencana di Kabupaten Sinjai, maupun di lokasi lainnya.

Berbagai aspek perlu dibenahi seperti aspek kepemimpinan dan sinergitas dalam persyarikatan. Penting untuk membangun koordinasi dan kerjasama dengan berbagai pihak, utamanya di tubuh PDM, amal usaha, institusi pemerintah (Badan Penanggulangan Bencana Daerah Propinsi dan Daerah, Dinas Sosial, Dinas Lingkungan Hidup, dll) dan seluruh kader, tokoh maupun simpatisan Muhammadiyah. LPB PDM memiliki peluang yang cukup besar jika mampu memanfaatkan potensi yang dimiliki, baik potensi dari sisi individu pengurus, maupun potensi lingkungan dan amal usaha yang dimiliki oleh Muhammadiyah di Kabupaten Sinjai. 


\section{Ucapan Terima Kasih}

Ucapan terima kasih yang sebesar-besarnya kepada Pimpinan Pusat Muhammadiyah. Tulisan ini merupakan hasil dari Hibah Riset Muhammadiyah sesuai dengan perjanjian kontrak No. 0984.029/I.3/D/2019.

\section{Daftar Pustaka}

Adhitya, Barry dan Widhyanto Muttaqien. 2009. Muhammadiyah dan Kesiapsiagaan Bencana. Risalah MDMC : Yogyakarta

Akbar, N. Al. (2012). JEJARING MUHAMMADIYAH ( Sebuah Analisis Recovery Bencana Merapi Yang Dilakukan Organisasi Muhammadiyah ). Jurnal Sosiologi Islam, 2(2), 50.

Baidhawy, Z. (2015). The role of faith-based organization in coping with disaster management and mitigation Muhammadiyah's experience. Journal of Indonesian Islam, 9(2), 167-194. https://doi.org/10.15642/JIIS.2015.9.2.167-194

Dewi, I. K., Istiadi, Y., \& Istiadi, Y. (2016). Mitigasi Bencana pada Masyarakat Tradisional dalam Menghadapi Perubahan Iklim di Kampung Naga Kecamatan Salamu Kabupaten Tasikmalaya. Jurnal Manusia Dan Lingkungan, 23(1), 129. https://doi.org/10.22146/jml.18782

Juliawati, N. (2013). Koordinasi dan Usaha Koordinasi dalam Organisasi: Sebuah Kerangka Studi. Journal of Chemical Information and Modeling, 53(9), 1689-1699. https://doi.org/10.1017/CBO9781107415324.004

Kusumasari, B. (2014). Manajemen Bencana dan Kapabilitas Pemrintah Lokal. Yogyakarta: Gava Media.

Larasati, D. A. B. H. (2016). Kajian kelembagaan dan regulasi penanggulangan bencana di kabupaten bojonegoro, 74-92.

Muhammadiyah, P. (2019). Berita Resmi Muhammadiyah Nomor 03/ 2015-2020/ Rabi'ul Akhir 1439 H/ Januari 2018 M, 1, 1-476. https://doi.org/10.1017/CBO9781107415324.004

Nugroho, R. B., Mustam, M., \& Lituhayu, D. (2019). Manajemen Bencana Dalam Penanggulangan Bencana Di Badan Penanggulangan Bencana Daerah (Bpbd) Kota Semarang. Jurnal Administrasi Publik, 1-13.

Peraturan Menteri Republik Indonesia Nomor 21 Tahun 2008 Tentang Penyelenggaraan Penanggulangan Bencana. (2008).

Putra, H. A. (2018). Studi Kualitatif Kesiapsiagaan Tim Komite Bencana Rumah Sakit PKU Muhammadiyah Bantul dalam Menghadapi Bencana. Health Sciences and Pharmacy Journal, 2(1), 8. https://doi.org/10.32504/hspj.v2i1.22

Rahman, A. Z. (2015). Kajian Mitigasi Bencana Tanah Longsor di Kabupaten Banjarnegara. Gema Publika: Jurnal Manajemen Dan Kebijakan Publik, 1(1), 1-14.

Slamet, C., Rahman, A., Sutedi, A., Darmalaksana, W., Ramdhani, M. A., \& Maylawati, D. S. (2018). Social Media-Based Identifier for Natural Disaster. IOP Conference Series: Materials Science and Engineering, 288(1). https://doi.org/10.1088/1757-899X/288/1/012039

Sugiharyanto et. all. (2014). Persepsi Mahasiswa Pendidikan IPS Terhadap Mitigasi Bencana Gempa Bumi. Journal of Chemical Information and Modeling, 53(9), 1689-1699. https://doi.org/10.1017/CBO9781107415324.004

Wulandari, C., Budiono, P., \& Nurrochmat, D. R. (2016). Kesiapan Daerah Dalam Implementasikan Program Tentang Pemerintahan Daerah. Risalah Kebijakan Pertanian Dan Lingkungan, 3 (2)(Agustus), 108-116. https://doi.org/10.20957/jkebijakan.v3i2.15512 